\title{
Trends for the Application of Passion Fruit Industrial By-Products: A Review on the Chemical Composition and Extraction Techniques of Phytochemicals
}

\author{
Juliane Viganó, Julian Martinez* \\ Department of Food Engineering, College of Food Engineering, University of Campinas, Campinas, Brazil
}

\begin{abstract}
This work presents a review on the composition and extraction techniques for recovering phytochemicals from passion fruit by-products. The review approaches on the characteristics of each phytochemical and its benefits to human health. It was observed that the by-products of passion fruit contain a range of interesting substances, and for their recovery the application of environmentally friendly extraction techniques, such as supercritical fluid extraction (SFE) and pressurized liquid extraction (PLE), are suggested as single or sequential procedures. The future perspectives of this review encourage the application of these techniques to a complete recovery of passion fruit by-products.
\end{abstract}

Keywords By-Products, Phytochemicals, Supercritical fluid extraction, Pressurized liquid extraction, Sequential extraction, Passion fruit

\section{Introduction}

Researches carried out in the last years have demonstrated the growing interest in recovering phytochemicals from vegetal matrices. The main goal of this recovery is to obtain compounds with biological activities for use in drugs, cosmetics and as additives for foods. Thus, the present work shows a review on a particular case. An approach on the phytochemical compounds contained in the passion fruit industrial by-products and on the emerging techniques to extract such compounds is presented. Researches performed with edible parts, by-products and aerial parts indicate that passion fruit is a rich source of phenolic compounds [1-4], fatty acids [5], tocopherols, tocotrienols [6] and carotenoids [7], compounds of high nutritional value, which are related to many health benefits.

The industrial processing of passion fruit pulp generates a considerable volume of by-products due to the separation of rind and bagasse. It is estimated that these materials correspond to $60-70 \%$ of the fruit mass $[8,9]$. Therefore, the development of techniques designed to use this type of material can add value and reduce the environmental impacts of its inappropriate disposal.

Several factors lead to chemical reactions that can degrade bioactive compounds limiting their use. To

* Corresponding author:

julian@unicamp.br (Julian Martinez)

Published online at http://journal.sapub.org/fph

Copyright (C) 2015 Scientific \& Academic Publishing. All Rights Reserved eliminate such limitations, extractions using pressurized fluids are a good alternative. The extraction techniques that employ supercritical fluids (SFE - Supercritical Fluid Extraction) or subcritical fluids (PLE - pressurized liquid extraction) show some advantages when compared to conventional extraction techniques. Among these advantages, the selectivity and low generation of solvent waste seem to be the most attractive. However, some drawbacks may occur with respect to the solubility of target compounds. In order to overcome this problem and to increase the extraction efficiency, some authors suggest sequential extractions, in which different extraction techniques are applied to the same raw material.

Few works were found addressing the recovery of bioactive compounds from passion fruit industrial by-products. In addition, there is no record of works that have fully used passion fruit by-products through sequential extraction processes. Taking the mentioned information into account, this paper has as objective to discuss the reasons that make the passion fruit by-products an interesting source of phytochemicals and presents trends for their recovery using clean and efficient technologies.

\section{The Yellow Passion Fruit}

The genus Passiflora includes about 500 species. Among them, the specie Passiflora edulis is the most known, being widely used by the food industry, and used in America and Europe as a sedative or tranquillizer. This specie, commonly called sour passion fruit or yellow passion fruit, is native from Brazil, but has also been grown in other continents [3]. 
The fruits, as shown in Figure 1, are berry type and have the seeds involved by the pulp and the fleshy aryl. The rind is composed by epicarp, which corresponds to the external layer of green to yellow color, and by the mesocarp, which is the white internal layer [10].

Brazil is the largest producer and consumer of yellow passion fruit. This specie is produced in $95 \%$ of the passion fruit orchards [3]. According to data from the Brazilian Institute of Geography and Statistics - IBGE [11], the production of this fruit in 2012 reached 776.097 tons. Brazilian Northeast and Southeast regions are the main responsible for this production.

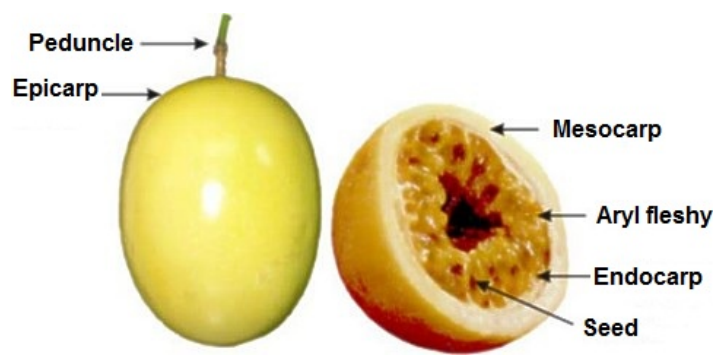

Figure 1. Passion fruit morphology

The cultivation of passion fruit is primarily focused on the juice and pulp industry, especially due to its more acidic taste and higher yield [10]. For obtaining the pulp, rind (epicarp and mesocarp) and bagasse (seed and aryl fleshy) are separated, resulting in by-products of the passion fruit processing industry. In most cases, this amount of biomass is used for animal feed or deposed on orchards to act as fertilizer. Although in small amounts, the rind has already been used for the formulation of flour, and the seeds are destined to the extraction of oil for cosmetics. The use of these wastes has environmental and economic advantages, since it prevents the inadequate disposal of biomass in the environment and can generate income through the formulation of new products with high added value.

\section{Composition of Passion Fruit By-Products}

The interest on the search for natural antioxidants for use in foods, aiming to decrease the lipid oxidation rate, or for pharmaceutical applications to prevent chronic diseases related to the production of free radicals, has increased in the recent years. Moreover, results of researches conducted with passion fruit by-products have been disclosed and show that the bagasse and rind are sources of several compounds of nutritional importance.

\subsection{Bagasse}

The passion fruit bagasse, as described previously, is composed by fleshy aryl and seeds. Bibliographic data regarding the composition of the fleshy aryl was not found. On the other hand, the seeds have been characterized and explored for different purposes. The main components of passion fruit seeds are oil and fibers [12]. The oil is used to produce cosmetics and may be found commercially. Linoleic acid is one of the main fatty acids of passion fruit oil (around $72-73 \%$ ), followed by oleic acid (13-16\%) and palmitic acid $(8-9 \%)[5,6]$. For human health, polyunsaturated fatty acids play important roles in the maintenance of cell membranes, brain function and the transmission of nerve impulses, and the growth and development of the cardiovascular system $[8,13]$.

Researches have also pointed that the passion fruit seed is a source of other substances, such as precursors of vitamin $\mathrm{E}$ (tocopherols and tocotrienols). Malacrida and Jorge [6] identified and quantified three fractions of tocopherols in passion fruit oil. They reported the following values for the fractions $\beta$-, $\gamma$ - e $\delta$ - tocopherol: $54.0,166.6$ e $278.7 \mathrm{mg} / \mathrm{kg}$ oil, respectively. Vitamin $\mathrm{E}$ consists of eight distinct molecules $\alpha$-, $\beta$-, $\gamma$ - e $\delta$-tocopherol e $\alpha$-, $\beta$-, $\gamma$ - e $\delta$-tocotrienol (Table 1 ), collectively named as tococromanols and tocols. These compounds have a chromanol group in one end attached to a long isoprenoid chain. Depending on the nature of the isoprenoid chain, a distinction is made between tocopherols (containing a saturated phytyl chain) or tocotrienols (unsaturated geranylgeranyl chain) [14].

Table 1. Chemical structures of tocols

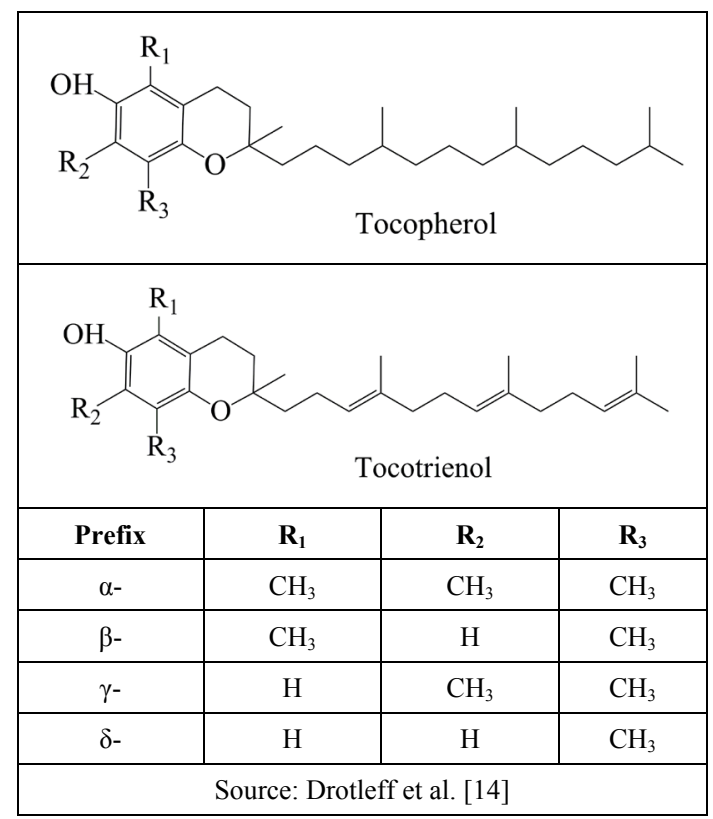

Numerous benefits for human health have been attributed to this class of compounds. Tocols delay the progress of a series of degenerative diseases, act on the protection against cancer and cardiovascular diseases, and have the function of reducing cholesterol in blood [15-17].

Carotenoids are a extensively studied class of compounds in the passion fruit juice. Nevertheless, works addressing the identification and quantification of carotenoids in passion fruit oil from seeds were not found. On the other hand, Ferreira et al. [18] investigated the total carotenoids of refined oil, obtained by cold pressing and Soxhlet, and the 
reported carotenoid content was 2.3, 4.6 and $19.7 \mu \mathrm{g} / \mathrm{g}$ oil, respectively. Carotenoids are known as responsible for many functional properties as antioxidant activity, prevention of cardiovascular disease, cancer, macular degeneration and in some cases pro-vitamin A [19].<smiles>Oc1cc(O)cc(C2c3c(/C=C/c4ccc(O)c(O)c4)cc(O)cc3OC2c2ccc(O)c(O)c2)c1</smiles>

(a) (b)<smiles>Oc1ccc(/C=C/c2cc(O)cc(O)c2)cc1</smiles><smiles>Oc1cc(O)cc(C=Cc2ccc(O)c(O)c2)c1</smiles>

(c)

Figure 2. Chemical structure of (a) Scirpusin B, (b) resveratrol and (c) piceatannol

Recent studies have reported the presence of phenolic compounds in passion fruit seeds. Matsui et al. [20] found piceatannol and resveratrol (Figure 2), and reported that piceatannol has positive effect in inhibiting melanogenesis and collagen synthesis. The observed amounts of piceatannol and resveratrol were 2.2 and $0.1 \mathrm{mg} / \mathrm{g}$ of dried seed, respectively. Sano et al. [21], apart from these two substances, found another phenolic compound known as Scirpusin B (Figure 2), but the authors quantified only piceatannol and Scirpusin B, which amounts were 5.7 and $3.6 \mathrm{mg} / \mathrm{g}$ of dried seed, respectively. Matsumoto et al. [22] used Scirpusin B for the evaluation of the coronary circulation of rats and found that this compound caused the increase in coronary blood flow via production of nitric oxide and vasodilating prostanoids. Scirpusin B is implicated to have beneficial effects on preventing cardiac events and atherosclerosis by increasing these substances responsible for vasodilatation.

Table 2 shows a comparison between substances found in passion fruit seeds and other sources. It can be observed that the fatty acid profile of passion fruit seeds is similar to that of seeds of other fruits, such as grape and guava. These three types of seeds are rich in polyunsaturated fatty acids. Regarding tocols, the presented sources do not resemble in the concentration. According the presented data, the carotenoid concentration in passion fruit seeds is lower than in pequi and buriti oils. However, this same reference (Ferreira et al. [18]) examined the same oil in terms of antioxidant activity, and passion fruit seed oil presented was the most active. This is possibly due to the content of tocols or phenolics, which proved to have antioxidant activity. As can be observed, passion fruit seeds present levels of piceatannol and resveratrol comparable to already recognized sources of these compounds.

Table 2. Comparison between the contents of substances of passion fruit seeds with other sources

\begin{tabular}{|c|c|c|c|c|}
\hline Fatty acids (\%) & Passion fruit seed oil [5] & $\begin{array}{c}\text { Peach almond oil } \\
{[23]}\end{array}$ & $\begin{array}{c}\text { Grape seed oil } \\
\text { [24] }\end{array}$ & $\begin{array}{c}\text { Guava seed oil } \\
{[25]}\end{array}$ \\
\hline Linoleic & 73 & 19 & $70-74$ & 71 \\
\hline Oleic & 16 & 72 & $13-17$ & 9 \\
\hline Palmitic & 9 & 6 & $5-9$ & 10 \\
\hline Linolenic & 0,3 & 0 & $0.3-0.7$ & 0.5 \\
\hline $\begin{array}{l}\text { Tocols (mg/100g } \\
\text { oil) }\end{array}$ & Passion fruit seed oil [6] & $\begin{array}{c}\text { Rice bran } \\
\text { oil [26] }\end{array}$ & $\begin{array}{c}\text { Grape seed oil } \\
{[24]}\end{array}$ & Guava seed oil [6] \\
\hline $\begin{array}{c}\alpha-/ \beta-/ \gamma-/ \\
\delta \text {-Tocopherol }\end{array}$ & $\begin{array}{c}0 / 5.4 / \\
16.6 / 27.8\end{array}$ & $\begin{array}{c}179 / 1 / \\
55 / 0\end{array}$ & $\begin{array}{c}19.9 / 0 / \\
6.2 / 0 \\
\end{array}$ & $\begin{array}{c}10.7 / 0.3 / \\
55 / 0.5\end{array}$ \\
\hline $\begin{array}{c}\alpha-/ \beta-/ \gamma-/ \\
\delta \text {-Tocotrienol }\end{array}$ & - & $\begin{array}{l}96 / 0.7 / \\
588 / 19\end{array}$ & $\begin{array}{l}2.6 / 0 / \\
198 / 0\end{array}$ & - \\
\hline Total carotenoids & $\begin{array}{c}\text { Passion fruit seed oil } \\
{[18]}\end{array}$ & Pequi oil [18] & Babaçu oil [18] & Buriti oil [18] \\
\hline & $2-20$ & 275 & 20 & 693 \\
\hline $\begin{array}{l}\text { Phenolic }(\mathrm{mg} / \mathrm{g} \\
\text { seed) }\end{array}$ & $\begin{array}{l}\text { Passion fruit seed [20, } \\
21]\end{array}$ & Grape seed [27] & \multicolumn{2}{|c|}{$\begin{array}{c}\text { Rhodomyrtus tomentosa } \\
\text { seed }[28]\end{array}$} \\
\hline Piceatannol & $2-6$ & NQ & \multicolumn{2}{|c|}{$3-7$} \\
\hline Resveratrol & 0.1 & $1.1-3.2$ & \multicolumn{2}{|c|}{ NI } \\
\hline Scirpusin B & 3.6 & NI & \multicolumn{2}{|c|}{ NI } \\
\hline
\end{tabular}




\subsection{Rind}

The passion fruit rind is composed mainly by carbohydrates [29]. Its elevated pectin content has made it a source for the extraction of this substance and for the formulation of flour. However, research has revealed the rind as a source of interesting nutrients such as the phenolic compounds presented on Table 3 .

The substances presented on Table 3 are phenolic compounds belonging to the class of C-glycosyl flavonoids. Their molecular structures are characterized by the presence of the flavan group, which comprises fifteen carbon atoms arranged into three rings, and five radicals, as shown in Table 4 [33].

Flavonoids are secondary metabolites that occur widely in plants. The function of those substances in the plant is wide. They act on protection against the harmful effects of UV rays and pathogens such as viruses, fungi, insects and bacteria. Besides, they contribute to the pigmentation and control of plant hormones and enzymes [33, 34]. Regarding human health, flavonoids have sedative properties and play an important protective role against atherosclerosis, brain disorders and cancer [33, 35]. Part of the mentioned functions is due to the antioxidant activity of these compounds. Flavonoids are natural antioxidants that act as reducing agents, hydrogen donors, oxygen neutralizing and chelating metals that could initiate or propagate chain reactions [36].

The substances contained in the passion fruit bagasse and rind represent an opportunity for adding value to these by-products. Therefore, techniques that allow the separation of these substances from the vegetable matrix are necessary. The next section addresses extraction processes that can be applied to separate and isolate the bioactive components from passion fruit residues.

Table 3. Phenolic compounds identified in species of Passiflora genus

\begin{tabular}{|c|c|c|c|}
\hline Compound & Part of plant & Specie & Reference \\
\hline Vicenin-2 & $\begin{array}{l}\text { Leaves and pericarp } \\
\text { Leaves }\end{array}$ & $\begin{array}{l}\text { P. edulis var. flavicarp } \\
\text { P. tripartita var. mollissima }\end{array}$ & [4] \\
\hline 6,8-di- $C$ - glycosylchrysin & Leaves and pericarp & P. edulis var. flavicarp & [4] \\
\hline Spinosin & Leaves and pericarp & P. edulis var. flavicarp & [4] \\
\hline Swertisin & Leaves & P. tripartita var. mollissima & [4] \\
\hline Vitexina-2"-O- rhamnoside & $\begin{array}{l}\text { Leaves and pericarp } \\
\text { Leaves } \\
\text { Leaves }\end{array}$ & $\begin{array}{l}\text { P. alata } \\
\text { P. quadrangulares } \\
\text { P. manicata }\end{array}$ & [4] \\
\hline Isoorientin & $\begin{array}{l}\text { Rind } \\
\text { Rind } \\
\text { Leaves and pericarp } \\
\text { Leaves } \\
\text { Leaves and pericarp } \\
\text { Leaves } \\
\text { Leaves } \\
\text { Pulp }\end{array}$ & $\begin{array}{l}\text { P. edulis } \\
\text { P. edulis } \\
\text { P. edulis var. flavicarp } \\
\text { P. alata } \\
\text { P. tripartita var. molissima } \\
\text { P. manicata } \\
\text { P. edulis } \\
\text { P. edulis }\end{array}$ & {$[3,4,30-32]$} \\
\hline Orientin & $\begin{array}{l}\text { Leaves } \\
\text { Leaves } \\
\text { Leaves and pericarp } \\
\text { Leaves }\end{array}$ & $\begin{array}{l}\text { P. edulis var. flavicarp } \\
\text { P. alata } \\
\text { P. tripartita var. molíssima } \\
\text { P. manicata }\end{array}$ & [4] \\
\hline Isovitexin & $\begin{array}{l}\text { Leaves } \\
\text { Leaves } \\
\text { Leaves and pericarp } \\
\text { Leaves } \\
\text { Leaves }\end{array}$ & $\begin{array}{l}\text { P. edulis var. flavicarp } \\
\text { P. alata } \\
\text { P. tripartita var. molíssima } \\
\text { P. manicata } \\
\text { P. edulis }\end{array}$ & {$[3,4]$} \\
\hline Vitexin & $\begin{array}{l}\text { Leaves } \\
\text { Leaves } \\
\text { Leaves } \\
\text { Leaves }\end{array}$ & $\begin{array}{l}\text { P. edulis var. flavicarp } \\
\text { P. tripartita var. molíssima } \\
\text { P. manicata } \\
\text { P. edulis }\end{array}$ & {$[3,4]$} \\
\hline
\end{tabular}


Table 4. Chemical structure of C-glycosyl flavonoids

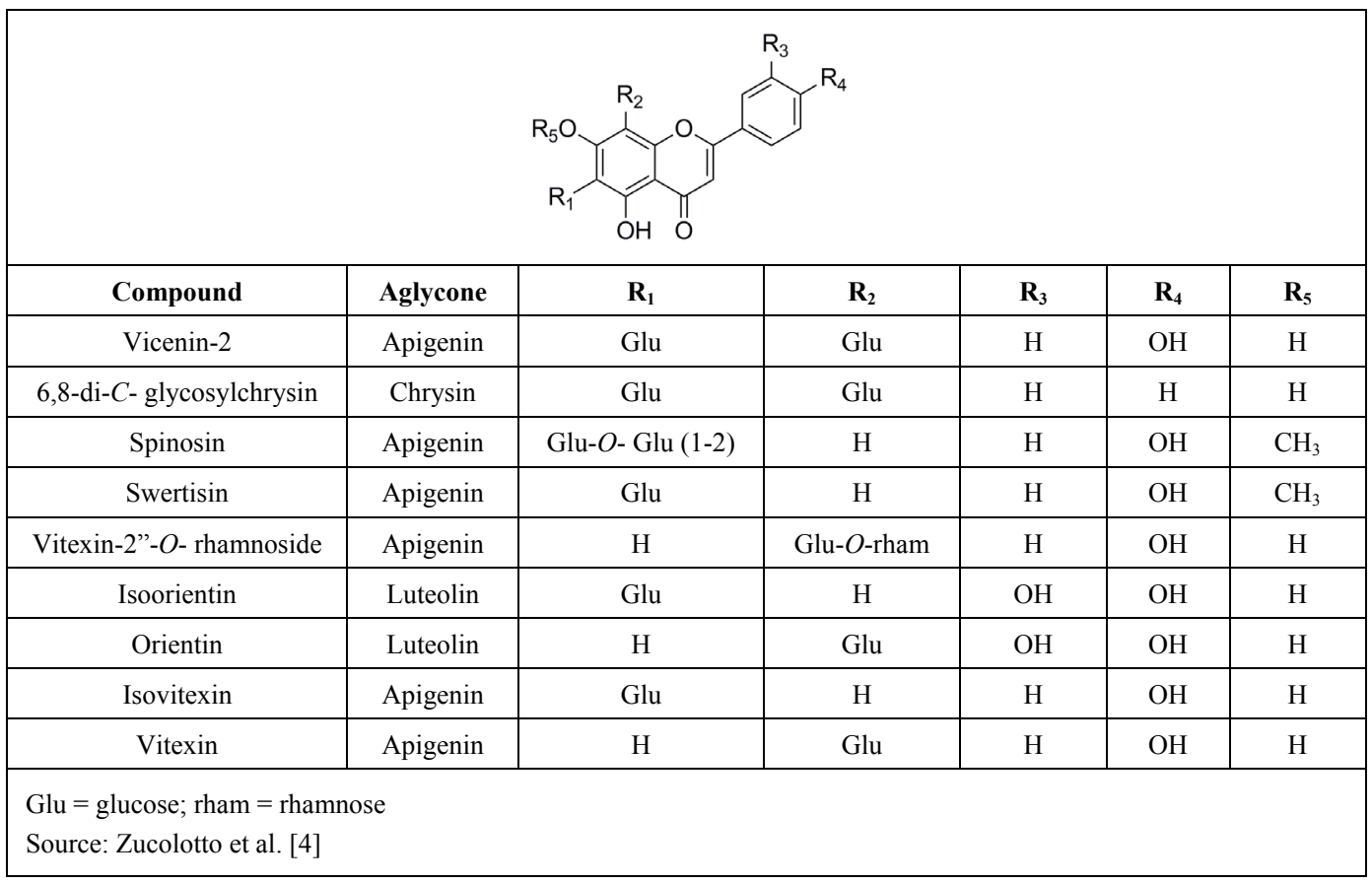

\section{Extraction Process}

The separation process of one or more components from a complex mixture is a requirement to several unit operations in food and chemical industries. Usually, the main objective of this operation is to remove a specific component to add value to the product. The specific component can be a residue, an interesting substance or both. The separation process can be classified according to the nature of the material submitted to separation, based on unit operations or classified by the type of phases in contact, such as solid-liquid, liquid-liquid, among others [37]. Basically, the separation of substances from vegetable matrices is classified as solid-liquid extraction, and can be carried out through conventional or non-conventional methods.

\subsection{Conventional Extraction Methods}

Conventional extraction methods are defined as classical techniques based on the extraction capacity of different solvents and/or application of heat and shaking. The classical techniques for obtaining substances from vegetable matrixes are Soxhlet and maceration. Both techniques were already used to obtain extracts from passion fruit by-products. Malacrida and Jorge [6] obtained oil from passion fruit seeds using Soxhlet and Cazarin et al. [10] extracted bioactive compounds from the rind by maceration.

The advantage of both techniques is the simplicity of the systems and, therefore, low cost to assemble the extraction unit. On the other hand, conventional techniques have drawbacks such as high extraction times, the use of large amounts of solvent [38], low selectivity, the need for solvent evaporation and decomposition of labile compounds $[13,39$,
40]. Thus, more environmentally friendly techniques that do not present health risks and provide high-quality extracts may be applied.

\subsection{Non-conventional Extraction Methods}

Extraction techniques that use pressurized fluids, ultrasound, enzymes, microwaves and electric pulse have shown promising results. Besides supplying the deficiencies of conventional methods, some of these techniques can be considered as "green" or environmentally friendly.

Extractions using pressurized fluids, besides reducing the extraction time and the amount of used solvent, can be more selective for obtaining target compounds. The process selectivity and velocity are consequences of the solvent physical and chemical properties, which in some cases can be controlled by changing the extraction parameters. In ideal solid-liquid extraction processes, the target compound must have high solubility in the employed solvent. Meanwhile, other components of the solid matrix should not be solubilized. In real processes this is rarely achieved. For this reason, several studies have sought to optimize conditions as the solvent/feed ratio, particle size, temperature, pressure, time and solvent flow rate to obtain the best performance in terms of the target compound [39]. Two extraction methods using pressurized fluids are commonly used: supercritical fluid extraction (SFE) and pressurized liquid extraction (PLE).

\subsubsection{Supercritical Fluid Extraction (SFE)}

Supercritical fluids are extensively used for extracting compounds from a large variety of matrices. Carbon dioxide $\left(\mathrm{CO}_{2}\right)$ is the most used solvent in SFE, since it is secure, 
nontoxic and has high solubilization power, which provides high mass transfer rates. In addition, it is widely available, has low cost and can be obtained with high purity. Its critical point $\left(7,34 \mathrm{MPa}\right.$ and $\left.31,06^{\circ} \mathrm{C}\right)$ allow obtaining extracts without submitting them to thermal damage [41]. On the other hand, the disadvantage of the use of this technique is the high investment cost for the construction of equipment. This is another reason to focus on obtaining extracts with high added value from this process.

Supercritical $\mathrm{CO}_{2}$ extraction processes $\left(\mathrm{SC}-\mathrm{CO}_{2}\right)$ present an important tool based on the tunable solvent properties, i.e., the selectivity of $\mathrm{SC}-\mathrm{CO}_{2}$ can be adjusted by varying temperature and pressure in order to obtain fractions enriched in desirable compounds [42-44]. The economic value of extracts can be increased through the recovery of fractions rich in desired components, and this can be achieved after comprehending the $\mathrm{SC}-\mathrm{CO}_{2}$ mechanisms.

There is a region above the critical point in which every substance is a single phase fluid, non-condensing and showing some typical physicochemical properties typical of gases and liquids (Table 5), i.e., the density approaches that of a liquid while its viscosity is close to those of gases. The solvation capacity of $\mathrm{CO}_{2}$ in the supercritical state depends on its density. The higher the density, smaller spaces between the molecules and bigger interactions between them are reached $[45,46]$. The highest density values are attained by combining low temperatures (but no lower than the critical temperature) and high pressures.

Table 5. Density and viscosity values of $\mathrm{CO}_{2}$

\begin{tabular}{|l|c|c|}
\hline \multicolumn{1}{|c|}{ State } & $\begin{array}{c}\text { Density } \\
\left(\mathrm{kg} / \mathrm{m}^{3}\right)\end{array}$ & $\begin{array}{c}\text { Viscosity } \\
(\mu \mathrm{Pa} . \mathrm{s})\end{array}$ \\
\hline Liquid $\left(27^{\circ} \mathrm{C} ; 50 \mathrm{MPa}\right)$ & 1029 & 133 \\
\hline Gas $\left(40^{\circ} \mathrm{C} ; 0,1 \mathrm{MPa}\right)$ & 2 & 16 \\
\hline Supercritical $\left(40^{\circ} \mathrm{C} ; 10 \mathrm{MPa}\right)$ & 632 & 17 \\
\hline \multicolumn{2}{|l}{ Source: Williams and Clifford $[47]}$. \\
\hline
\end{tabular}

The SFE process is carried out in solid matrixes by means of the continuous contact between the solvent and the solid phase. In most cases, the solid is placed in a fixed bed and the solvent flows through it. After the extraction procedure, the solvent loaded with the extracted solute leaves the extractor and migrates to the precipitator or separator. The precipitation of the solute is made by simple reduction of the pressure below the critical point.

Extraction phenomena can be separated in three parts (Figure 3). The first corresponds to the constant extraction rate (CER) period, which is characterized by the extraction of the solute that covers the outer surface of the particles of the vegetable matrix. This is considered an easily accessible solute. In this step the mass convection mechanism predominates in the process. The second period, falling extraction rate (FER), starts when there is insufficient amount of solute to maintain the constant extraction rate. The last period is diffusion controlled (DC), in which the process is controlled only by the diffusion of the solvent inside the particles and the diffusion of the solvent/solute to their surface [48].

The application of supercritical $\mathrm{CO}_{2}$ results in good performance to extract nonpolar substances such as fatty acids, carotenoids, tocopherols and tocotrienols. Liu et al. [5] suggested SFE at temperature of $56{ }^{\circ} \mathrm{C}$, pressure of $26 \mathrm{MPa}$ and extraction time of $4 \mathrm{~h}$ to recover oil from passion fruit with global yield of $25.83 \%$. However, the authors did not identify or quantify minor lipids such as carotenoids and tocols. Although few studies have reported data on the extraction conditions of passion fruit by-products, there is a vast amount of literature work whose data show the best conditions to recover target compounds from other vegetable matrices using SFE.

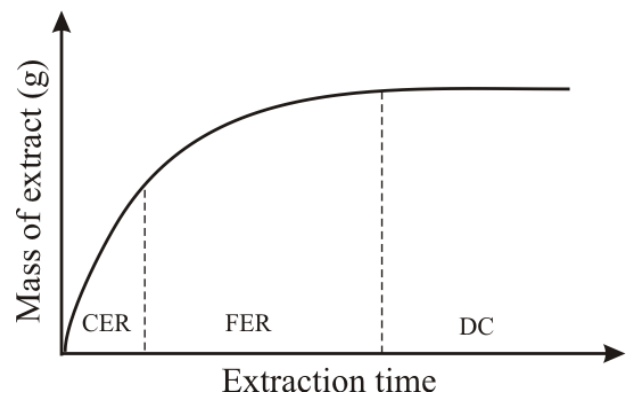

Figure 3. Typical extraction curve of a SFE process

The commonly studied variables in SFE are pressure, temperature, solvent flow rate, extraction time, particle size and extraction bed properties as height/diameter ratio. However, most studies focus efforts on the study of temperature and pressure. The employed temperatures are generally between 40 and $70^{\circ} \mathrm{C}$. The lower limit is due to the proximity of the critical temperature of $\mathrm{CO}_{2}$ and the upper limit affects the density of this solvent. Lower densities are achieved with increasing temperature, resulting in lower extraction yield and high energy consumption. Regarding pressure, most works explore the range 10-50 MPa. Pressure has the opposite effect of temperature on $\mathrm{CO}_{2}$ density, i.e., increasing the pressure the density of $\mathrm{CO}_{2}$ increases, and consequently its solvation capacity becomes greater. Pressures above the presented range lead to high energy costs and lower pressures approach the limit of the critical pressure of $\mathrm{CO}_{2}$.

Many works have concentrated efforts to identify the variables of SFE that produce better results for the extraction of interesting compounds. The best conditions for extracting tocols seem to be dependent of raw material. Ciftci et al. [49] identified $70^{\circ} \mathrm{C}$ and $49.6 \mathrm{MPa}$ as the best condition to obtain total tocols from corn dried grans. Liu et al. [50] found $50^{\circ} \mathrm{C}$ and $15 \mathrm{MPa}$ as the optimal condition to obtain total tocopherols from pomegranate. Finally, Sarmento et al. [51] identified $40^{\circ} \mathrm{C}$ and $20 \mathrm{MPa}$ to obtain total tocols from parboiled rice bran. With regard to carotenoids, Wijngaard et al. [39] made an extensive review on the SFE conditions and found that the extraction occurs at temperatures between $50-100^{\circ} \mathrm{C}$ and pressures between $30-40 \mathrm{MPa}$. In terms of fatty acids, the non-polar nature of these compounds make 
them easily extractable with supercritical $\mathrm{CO}_{2}$ under moderate pressures and temperatures, and in the case of thermolabile compounds, values should be set in the range of $35-50^{\circ} \mathrm{C}$. Low pressures are required to extract fatty acids, generally from $10 \mathrm{MPa}$, but the general rule is: the higher is the pressure, the larger is the solvent power and the smaller is the extraction selectivity [52]. SFE also can be used to recover phenolic compounds. However, in most cases the use of a cosolvent is needed. A wide variety of extraction temperatures have been reported as optimal for polyphenol extraction $\left(30-100^{\circ} \mathrm{C}\right)$. However, most authors usually affirm that the best temperatures are between 40 and $60^{\circ} \mathrm{C}$, and the optimal pressures are between 20 and $30 \mathrm{MPa}$. Water and ethanol are the recommended cosolvents, but amounts higher than $10 \%(\mathrm{~m} / \mathrm{m})$ are not recommended because the solvent can leave the supercritical state [39]. In addition, SFE can show low efficiency to obtain polar compounds like polyphenols. An alternative to overcome this problem is the use of PLE processes [39, 53].

\subsubsection{Pressurized Liquid Extraction (PLE)}

PLE is based on the use of solvents at high pressure and temperature, but not above the critical point. The main objective of this technique is to promote the extraction of compounds from solid or semisolid matrices in short time and using small amount of solvent. The main advantage of PLE over conventional extraction methods is that pressurized solvents remain in the liquid state when taken to temperatures higher than their boiling points. These conditions improve the solvation power of the liquids and the desorption kinetics from the solid matrix. In addition, as well as SFE, this extraction method is carried out in an environment free from oxygen and light, which reinforced its potential use in extractions of nutraceutical compounds $[54,55]$.

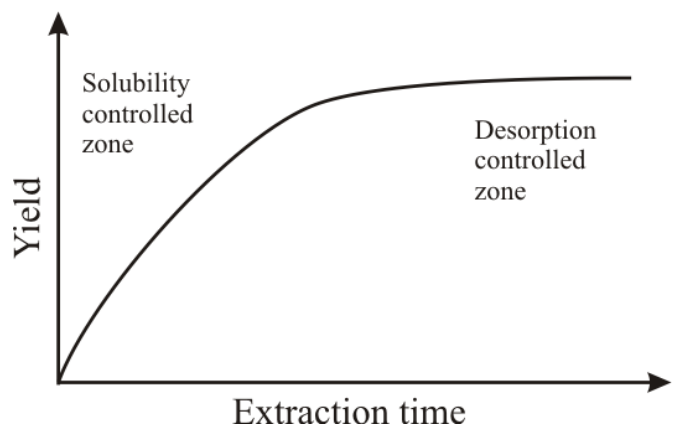

Figure 4. Typical curve of a PLE process. Adapted from Mustafa and Turner [56]

The PLE process can be divided in two stages. The first is a period when the extraction is controlled by the solubility, and the second is controlled by the diffusion of solutes in the solvent, as shown in Figure 4. The main solvents used in PLE are methanol, isopropanol, acetone, hexane and ether. Water and ethanol have been increasingly employed in the extraction of polyphenols, such as flavonoids and phenolic acids, because they are considered "green" solvents.
According to Mustafa and Turner [56], the use of solvent mixtures of two substances can help improving the solubility and increase the interaction with the target compound, i.e., one substance improves the solubility and the other improves the solute desorption.

No works were performed with passion fruit by-products employing PLE as extraction technique. However, several researches have indicated PLE as an alternative to recover phenolic compounds from a series of vegetable matrices. Wijngaard and Brunton [57] reported that the antioxidant activity of PLE extracts from apple pomace was increased 2.4 times in comparison to traditional methods.

According to Mustafa and Turner [56], temperature during the extraction is one of the critical factors that affect the efficiency and selectivity in PLE. The use of high temperatures improves the efficiency of the extraction as it helps the disruption of analyte-sample matrix interactions, decreases the surface tension of the solvent, solutes and matrix, decreases the viscosity of a liquid solvent and improves diffusion rate. On the other hand, the amount of co-extracted analytes might increase at higher temperatures, resulting in a decreased the selectivity of extraction. In addition, high temperatures might affect thermo-labile compounds that are subjected to disintegration and hydrolytic degradation. Regarding pressure, the use of high pressure helps forcing the solvent within the matrix pore to contact and extract the analytes. The use of high pressure during the extraction could result in the disruption of cells of the matrix, thus enhancing the mass transfer rate of the analyte from the sample to the solvent. However, the effect of pressure on the recovery of most substances is usually negligible in PLE, since liquids are known as uncompressible fluids.

It has been observed that among the process variables, temperature and solvent type are the most studied, since pressures above $10 \mathrm{MPa}$ have shown no significant effect on the characteristics of the extracts. PLE has been suitably used for the recovery of phenolic compounds from plant sources. The used temperature range is very wide $\left(40-200^{\circ} \mathrm{C}\right)$, while the most used solvents are ethanol and water, individually or in mixture [39]. In this type of process, both temperature and solvent are strongly dependent of the characteristics of the target compounds, due to the thermal degradation of the compound and its polarity.

\subsubsection{Sequential Extraction}

The researches mentioned in Section 3 indicate the passion fruit by-products as potential sources to extract fatty acids, tocols, carotenoids and phenolic compounds. However, drawbacks occur because fatty acids, tocols and carotenoids are nonpolar compounds, while phenolics are polar. Therefore, it becomes unviable to obtain separate fractions of these components through extractions with the same solvent. To deal with this problem and to increase the efficiency and selectivity of extractions some authors suggest sequential processes $[39,58,59]$, i.e., from the same 
solid matrix, extraction techniques as SFE and PLE could be applied to obtain fractions of extract with distinct chemical characteristics. The selectivity of $\mathrm{SC}-\mathrm{CO}_{2}$ enables obtaining different fractions of extracts, each one rich in tocols (at low $\mathrm{SC}-\mathrm{CO}_{2}$ density), fatty acids (at intermediate $\mathrm{SC}-\mathrm{CO}_{2}$ density) and carotenoids (at high $\mathrm{SC}-\mathrm{CO}_{2}$ density). Next, PLE can lead to the recovery of phenolic compounds in which the power of each solvent might be explored.

Some works involving combinations of high pressure techniques to extract bioactive compounds from vegetable sources have been reported. Paula et al. [60] obtained phenolic compounds from Arrabidaea chica employing sequential techniques and using $\mathrm{CO}_{2}$, water and ethanol as solvents. The authors achieved better results in terms of global yield and total phenolics when compared with conventional extraction. Serra at al. [61] extracted, in sequential steps, bioactive substances from cherries using $\mathrm{CO}_{2}$ and ethanol and concluded that the sequential process produces extracts more concentrated and with higher biological activity. Similar conclusions were obtained by Garmus et al. [62] and [63] for sequential extraction of pitanga and pepper-rosmarin leaves.

\section{Conclusions and Future Perspectives}

The chemical composition of passion fruit by-products encourages their recovery from industrial processes for novel applications and products. The researches reported in this work show that the passion fruit by-products are source of several phytochemical compounds of interest to food and pharmaceutical industries. The use of this type of material allows reducing the environmental damages, as well as adds value to a material that would be usually discarded.

The application of extraction techniques that employ pressurized fluids reinforces the appeal of using by-products, since the proposed techniques are considered environmentally friendly and enable the use of GRAS solvents, which are favourable for applications in food. In the same way, sequential extraction processes are seen with expectation for the recovery of phytochemicals from food by-products. Combined techniques promote a better exploration of the vegetal matrix, leading to the extraction of different classes of substances from the same source, and accordingly, leading to fractions of extract concentrated in target compounds. The passion fruit bagasse can be used as example to this approach because it is rich in polar compounds (oil, tocols and carotenoids) that can be recovered in steps by SFE, and nonpolar compounds such as polyphenols that can be properly obtained by PLE with ethanol and water as solvents.

\section{ACKNOWLEDGEMENTS}

The authors wish to thank to the FAPESP for the doctoral scholarship (Project $\mathrm{n}^{\circ}$ 2014/00372-8) and for financial support (Project n ${ }^{\circ}$ 2013/02203-6), and CAPES (2952/2011).

\section{REFERENCES}

[1] R. Martinez, P. Torres, M.A. Meneses, J.G. Figueroa, J.A. Pérez-Álvarez, M. Viuda-Martos, "Chemical, technological and in vitro antioxidant properties of mango, guava, pineapple and passion fruit dietary fibre concentrate", Food Chemistry, vol. 135, pp. 1520-1526, 2012.

[2] A.C. Oliveira, I.B. Valentim, C.A. Silva, E.J.H. Bechara, M.P. Barros, C.M. Mano, M.O.F. Goulart, "Total phenolic content and free radical scavenging activities of methanolic extract powders of tropical fruit residues", Food Chemistry, vol. 115, pp. 469-475, 2009.

[3] J.K. Silva, C.B.B. Cazarin, T.C. Colomeu, Â.G. Batista, L.M.M. Meletti, J.A.R. Paschoal, S. Bogusz Júnior, M.F. Furlan, F.G.R. Reyes, F. Augusto, M.R. Maróstica Júnior, R. de Lima Zollner, "Antioxidant activity of aqueous extract of passion fruit (Passiflora edulis) leaves: In vitro and in vivo study", Food Research International, vol. 53, pp. 882-890, 2013.

[4] S.M. Zucolotto, C. Fagundes, F.H. Reginatto, F.A. Ramos, L. Castellanos, C. Duque, E.P. Schenkel, "Analysis of C-glycosyl flavonoids from South American Passiflora species by HPLC-DAD and HPLC-MS", Phytochemical Analysis, vol. 23, pp. 232-239, 2012.

[5] S. Liu, F. Yang, C. Zhang, H. Ji, P. Hong, C. Deng, "Optimization of process parameters for supercritical carbon dioxide extraction of Passiflora seed oil by response surface methodology", The Journal of Supercritical Fluids, vol. 48 pp. 9-14, 2009.

[6] C.R. Malacrida, N. Jorge, "Yellow Passion Fruit Seed Oil (Passiflora edulis f. flavicarpa): Physical and Chemical Characteristics", Brazilian archives of biology and technology, vol. 55, pp. 127-134, 2012.

[7] B.S. Ferreira, C.G. de Almeida, M. Le Hyaric, V.E. de Oliveira, H.G.M. Edwards, L.F.C. de Oliveira, "Raman Spectroscopic Investigation of Carotenoids in Oils from Amazonian Products", Spectroscopy Letters, vol. 46, pp. 122-127, 2013.

[8] M.L. Zeraik, C.A.M. Pereira, V.G. Zuin, J.H. Yariwake, "Maracujá: um alimento funcional?", Brazilian Journal of Pharmacognosy, vol. 20, pp. 459-471, 2010.

[9] G.P. Gerola, N.V. Boas, J. Caetano, C.R.T. Tarley, A.C. Gonçalves, D.C. Dragunski, "Utilization of Passion Fruit Skin By-Product as Lead(II) Ion Biosorbent", Water, Air, \& Soil Pollution, vol. 224, pp. 1-11, 2013.

[10] C.B.B. Cazarin, J.K.d. Silva, T.C. Colomeu, R.d.L. Zollner, M.R. Maróstica Junior, "Capacidade antioxidante e composição química da casca de maracujá (Passiflora edulis)", Ciência Rural, vol. 44, pp. 1699-1704, 2014.

[11] IBGE, Produção agricola municipal 2012 (PAM2012), Instituto Brasileiro de Geografia e Estatística, [Online]. Available: http://www.ibge.gov.br/home/estatistica/pesquisa s/pesquisa_resultados.php?id_pesquisa=44, 2014.

[12] C.F. Chau, Y.L. Huang, "Characterization of passion fruit seed fibres - A potential fibre source", Food Chemistry, vol. 85, pp. 189-194, 2004. 
[13] J. Martínez, A.C.d. Aguiar, Extraction of Triacylglycerols and Fatty Acids Using Supercritical Fluids - Review, Current Analytical Chemistry, 10 (2014) 67-77.

[14] A.M. Drotleff, C. Bohnsack, I. Schneider, A. Hahn, W. Ternes, "Human oral bioavailability and pharmacokinetics of tocotrienols from tocotrienol-rich (tocopherol-low) barley oil and palm oil formulations", Journal of Functional Foods, vol. 7, pp. 150-160, 2014.

[15] X. Zhang, Y. Shen, W. Prinyawiwatkul, J.M. King, Z. Xu, "Comparison of the activities of hydrophilic anthocyanins and lipophilic tocols in black rice bran against lipid oxidation", Food Chemistry, vol. 141, pp. 111-116, 2013.

[16] M.T. Labuschagne, N. Mkhatywaa, B. Wentzel, E. Johansson, A.V. Biljon, "Tocochromanol concentration, protein composition and baking quality of white flour of South African wheat cultivars", Journal of Food Composition and Analysis, vol. 33, pp. 127-131, 2014.

[17] S.A. Heleno, L. Barros, M.J. Sousa, A. Martins, I.C.F.R. Ferreira, "Tocopherols composition of Portuguese wild mushrooms with antioxidant capacity", Food Chemistry, vol. 119, pp. 1443-1450, 2010.

[18] B.S. Ferreira, C.G. de Almeida, L.P. Faza, A. de Almeida, C.G. Diniz, V.L. da Silva, R.M. Grazul, M. Le Hyaric, "Comparative properties of Amazonian oils obtained by different extraction methods", Molecules, vol. 16, pp. 5875-5885, 2011.

[19] E. Murillo, D. Giuffrida, D. Menchaca, P. Dugo, G. Torre, A.J. Melendez-Martinez, L. Mondello, "Native carotenoids composition of some tropical fruits", Food Chemistry, vol. 140, pp. 825-836, 2013.

[20] Y. Matsui, K. Sugiyama, M. Kamei, T. Takahashi, T. Suzuki, Y. Katagata, T. Ito, "Extract of Passion Fruit (Passiflora edulis) Seed Containing High Amounts of Piceatannol Inhibits Melanogenesis and Promotes Collagen Synthesis", Journal of agricultural and food chemistry, vol. 58, pp. 11112-11118, 2010.

[21] S. Sano, K. Sugiyama, T. Ito, Y. Katano, A. Ishihata, "Identification of the strong vasorelaxing substance scirpusin $\mathrm{B}$, a dimer of piceatannol, from passion fruit (Passiflora edulis) seeds", Journal of agricultural and food chemistry, vol. 59, pp. 6209-6213, 2011.

[22] Y. Matsumoto, N. Gotoh, S. Sano, K. Sugiyama, T. Ito, Y. Abe, Y. Katano, A. Ishihata, "Effects of Scirpusin B, A polyphenol in passion fruit seeds, on the coronary circulation of the isolated perfused rat heart", International Journal of Medical Research \& Health Sciences, vol. 3, pp. 547-553, 2014.

[23] N. Mezzomo, B.R. Mileo, M.T. Friedrich, J. Martinez, S.R. Ferreira, "Supercritical fluid extraction of peach (Prunus persica) almond oil: process yield and extract composition", Bioresource Technology, vol. 101, pp. 5622-5632, 2010.

[24] L. Fiori, V. Lavelli, K.S. Duba, P.S.C. Sri Harsha, H.B. Mohamed, G. Guella, "Supercritical $\mathrm{CO}_{2}$ extraction of oil from seeds of six grape cultivars: Modeling of mass transfer kinetics and evaluation of lipid profiles and tocol contents", The Journal of Supercritical Fluids, vol. 94, pp. 71-80, 2014.

[25] G. Piombo, N. Barouh, B. Barea, R. Boulanger, P. Brat, M. Pina, P. Villeneuve, "Characterization of the seed oils from kiwi (Actinidia chinensis), passion fruit (Passiflora edulis) and guava (Psidium guajava), Oilseeds and fats", Crops and Lipids, vol. 13, pp. 195-199, 2006.

[26] C.M.P. Sarmento, S.R.S. Ferreira, H. Hense, "Supercritical fluid extraction (SFE) of rice bran oil to obtain fractions enriched with tocopherols and tocotrienols", Brazilian Journal of Chemical Engineering, vol. 23, pp. 243-249, 2006.

[27] T. PUSSA, J. FLOREN, P. KULDKEPP, A. RAAL, "Survey of Grapevine Vitis vinifera Stem Polyphenols by Liquid Chromatography-Diode Array Detection-Tandem Mass Spectrometry", Journal of Agriculture and Food Chemistry, vol. 54, pp. 7488-7494, 2006.

[28] T.N.H. Lai, C.M. André, R. Chirinos, T.B.T. Nguyen, Y. Larondelle, H. Rogez, "Optimisation of extraction of piceatannol from Rhodomyrtus tomentosa seeds using response surface methodology", Separation and Purification Technology, vol. 134, pp. 139-146, 2014.

[29] F.L. Oliveira, M.R.F. Nascimento, S.V. Borges, P.C.N. Ribeiro, V.R. Ruback, "Aproveitamento alternativo da casca do maracujá-amarelo (Passiflora edulis f. flavicarpa) para produção de doce em calda", Ciência e Tecnologia de Alimentos, vol. 22, pp. 259-262, 2002.

[30] M.L. Zeraik, J.H. Yariwake, Analysis of passion fruit rinds (Passiflora edulis): isoorientin quantification by hptlc and evaluation of antioxidant (radical scavenging) capacity, Química Nova, 35 (2012) 541-545.

[31] M.L. Zeraik, J.H. Yariwake, "Quantification of isoorientin and total flavonoids in Passiflora edulis fruit pulp by HPLC-UV/DAD”, Microchemical Journal, vol. 96, pp. 86-91, 2010.

[32] M.L. Zeraik, D. Serteyn, G. Deby-Dupont, J.N. Wauters, M. Tits, J.H. Yariwake, L. Angenot, T. Franck, "Evaluation of the antioxidant activity of passion fruit (Passiflora edulis and Passiflora alata) extracts on stimulated neutrophils and myeloperoxidase activity assays", Food Chemistry, vol. 128, pp. 259-265, 2011.

[33] I. Ignat, I. Volf, V.I. Popa, “A critical review of methods for characterisation of polyphenolic compounds in fruits and vegetables”, Food Chemistry, vol. 126, pp. 1821-1835. 2011.

[34] C.D. Stalikas, "Extraction, separation, and detection methods for phenolic acids and flavonoids", Journal of separation science, vol. 30, pp. 3268-3295, 2007.

[35] J.K. Silva, C.B.B. Cazarin, Â.G. Batista, M. Maróstica, "Effects of passion fruit (Passiflora edulis) byproduct intake in antioxidant status of Wistar rats tissues", LWT - Food Science and Technology, vol. 59, pp. 1213-1219, 2014.

[36] R. Tsao, R. Yang, "Optimization of a new mobile phase to know the complex and real polyphenolic composition: towards a total phenolic index using high-performance liquid chromatography", Journal of Chromatography A, vol. 1018, pp. 29-40, 2003.

[37] A.S. Grandison, M.J. Lewis, Separation processes - an overview, in: A.S. Grandison, M.J. Lewis (Eds.) Separation Processes in the food and Biotechnology Industies, Cambrige, United Kingdom: Woodhead Publishing Limited, pp. 1-15, 1996.

[38] D.T. Santos, R.N. Cavalcanti, M.A. Rostagno, C.L. Queiroga, M.N. Eberlin, M.A.A. Meireles, "Extraction of Polyphenols and Anthocyanins from the Jambul (Syzygium cumini) Fruit 
Peels", Food and Public Health, vol. 3 pp. 12-20, 2013.

[39] H. Wijngaard, M.B. Hossain, D.K. Rai, N. Brunton, "Techniques to extract bioactive compounds from food by-products of plant origin", Food Research International, vol. 46, pp. 505-513, 2012.

[40] A.M. Farías-Campomanes, C.N. Horita, M.A.R. Pollonio, M.A.A. Meireles, "Allicin-Rich Extract Obtained from Garlic by Pressurized Liquid Extraction: Quantitative Determination of Allicin in Garlic Samples", Food and Public Health, vol. 4, pp. 272-278, 2014.

[41] P. Santos, A.C. Aguiar, G.F. Barbero, C.A. Rezende, J. Martinez, "Supercritical carbon dioxide extraction of capsaicinoids from malagueta pepper (Capsicum frutescens L.) assisted by ultrasound", Ultrason Sonochemistry, vol. 22, pp. 78-88, 2015.

[42] N. Babovic, S. Djilas, M. Jadranin, V. Vajs, J. Ivanovic, S. Petrovic, I. Zizovic, "Supercritical carbon dioxide extraction of antioxidant fractions from selected Lamiaceae herbs and their antioxidant capacity", Innovative Food Science \& Emerging Technologies, vol. 11, pp. 98-107, 2010.

[43] G. Liu, X. Xu, Y. Gong, L. He, Y. Gao, "Effects of supercritical $\mathrm{CO}_{2}$ extraction parameters on chemical composition and free radical-scavenging activity of pomegranate (Punica granatum L.) seed oil", Food and Bioproducts Processing, vol. 90, pp. 573-578, 2012.

[44] I.M. Prado, G.H.C. Prado, J.M. Prado, M.A.A. Meireles, "Supercritical $\mathrm{CO}_{2}$ and low-pressure solvent extraction of mango (Mangifera indica) leaves: Global yield, extraction kinetics, chemical composition and cost of manufacturing", Food and Bioproducts Processing, vol. 91, pp. 656-664, 2013.

[45] G. Brunner, Gas extraction: an introduction to fundamentals of supercritical fluids and the application to separation processes, Darmstadt, Germany: Springer, 1994.

[46] G. Brunner, "Supercritical fluids: technology and application to food processing", Journal of Food Engineering, vol. 67, pp. 21-33, 2005.

[47] J.R. Williams, T. Clifford, Supercritical fluid methods and protocols, Darmstadt, Germany: Springer, 2000.

[48] H. Sovová, "Rate of the vegetable oil extraction with supercritical $\mathrm{CO}_{2}$ - I. Modelling of extraction curves", Chemical Engineering Science, vol. 49, pp. 409-414, 1994.

[49] O.N. Ciftci, J. Calderon, F. Temelli, "Supercritical carbon dioxide extraction of corn distiller's dried grains with solubles: experiments and mathematical modeling", Journal of Agriculture and Food Chemistry, v. 60, pp. 12482-90, 2012.

[50] G. Liu, X. Xu, Y. Gong, L. He, Y. Gao, "Effects of supercritical $\mathrm{CO}_{2}$ extraction parameters on chemical composition and free radical-scavenging activity of pomegranate (Punica granatum L.) seed oil", Food and Bioproducts Processing, vol. 90, n. 3, pp. 573-578, 2012.

[51] C.M.P. Sarmento, S.R.S. Ferreira, H. Hense, "Supercritical fluid extraction (SFE) of rice bran oil to obtain fractions enriched with tocopherols and tocotrienols", Brazilian Journal of Chemical Engineering, vol. 23, n. 2, pp. 243-249,
2006.

[52] T. Fornari, G. Vicente, E. Vazquez, M.R. Garcia-Risco, G. Reglero, "Isolation of essential oil from different plants and herbs by supercritical fluid extraction", Journal of Chromatography A, vol. 1250, pp. 34-48, 2012.

[53] I.C.N. Debien, M.A.A. Meireles, "Supercritical Fluid Extraction of Beta-ecdysone from Brazilian Ginseng (Pfaffia glomerata) Roots", Food and Public Health, vol. 4, pp. 67-73, 2014.

[54] Z.Y. JU, L.R. HOWARD, "Effects of solvent and temperature on pressurized liquid extraction of anthocyanins and total phenolics from dried red grape skin", Journal of agricultural and food chemistry, vol. 51, pp. 5207-5213, 2003.

[55] D.T. Santos, P.C. Veggi, M.A.A. Meireles, "Optimization and economic evaluation of pressurized liquid extraction of phenolic compounds from jabuticaba skins", Journal of Food Engineering, vol. 108, pp. 444-452, 2012.

[56] A. Mustafa, C. Turner, "Pressurized liquid extraction as a green approach in food and herbal plants extraction: A review", Analytica Chimica Acta, vol. 703, pp. 8-18, 2011.

[57] H. Wijngaard, N. Brunton, "The optimization of extraction of antioxidants from apple pomace by pressurized liquids", Journal of agricultural and food chemistry, vol. 57, pp. 10625-10631, 2009.

[58] F. Temelli, O.N. Ciftci, "Developing an integrated supercritical fluid biorefinery for the processing of grains", The Journal of Supercritical Fluids, vol. 96, pp. 77-85, 2015.

[59] J. Viganó, A.P.d.F. Machado, J. Martínez, "Sub- and supercritical fluid technology applied to food waste processing", The Journal of Supercritical Fluids, vol. 96, pp. 272-286, 2015.

[60] J.T. Paula, L.C. Paviani, M.A. Foglio, I.M.O. Sousa, F.A. Cabral, "Extraction of anthocyanins from Arrabidaea chica in fixed bed using $\mathrm{CO}_{2}$ and $\mathrm{CO}_{2} /$ ethanol/water mixtures as solvents", The Journal of Supercritical Fluids, vol. 81, pp. 33-41, 2013.

[61] A.T. Serra, I.J. Seabra, M.E.M. Braga, M.R. Bronze, H.C. de Sousa, C.M.M. Duarte, "Processing cherries (Prunus avium) using supercritical fluid technology. Part 1: Recovery of extract fractions rich in bioactive compounds", The Journal of Supercritical Fluids, vol. 55, pp. 184-191, 2010.

[62] T.T. Garmus, L.C. Paviani, C.L. Queiroga, P.M. Magalhães, F.A. Cabral, "Extraction of phenolic compounds from pitanga (Eugenia uniflora L.) leaves by sequential extraction in fixed bed extractor using supercritical $\mathrm{CO} 2$, ethanol and water as solvents", The Journal of Supercritical Fluids, vol. 86, pp. 4-14, 2014.

[63] T.T. Garmus, L.C. Paviani, C.L. Queiroga, F.A. Cabral, "Extraction of phenolic compounds from pepper-rosmarin (Lippia sidoides Cham.) leaves by sequential extraction in fixed bed extractor using supercritical $\mathrm{CO}_{2}$, ethanol and water as solvents", The Journal of Supercritical Fluids, vol. 99, pp. 68-75, 2015. 